\title{
Profile and analysis of diabetes chronic complications in Outpatient Diabetes Clinic of Cipto Mangunkusumo Hospital, Jakarta
}

\author{
Tri J.E. Tarigan, Em Yunir, Imam Subekti, Laurentius A. Pramono, Diah Martina
}

Department of Internal Medicine, Faculty of Medicine, Universitas Indonesia, Jakarta, Indonesia

\section{ABSTRAK}

Latar belakang: Komplikasi kronis diabetes meningkatkan morbiditas, mortalitas, disabilitas, dan biaya kesehatan pasien diabetes. Dalam setting rawat jalan, keberadaan data komplikasi kronis diabetes melitus tipe 2 bermanfaat dalam pencegahan, edukasi, dan terapi pasien. Tujuan studi ini adalah mendeskripsi dan menganalisis karakteristik komplikasi kronis diabetes pada pasien rawat jalan.

Metode: Studi potong lintang dilakukan terhadap 155 pasien di Poliklinik Rawat Jalan Diabetes Rumah Sakit Cipto Mangunkusumo pada tahun 2010. Data sekunder berasal dari rekam medis pasien berdasarkan hasil anamnesis, pemeriksaan fisis, pemeriksaan kaki, laboratorium, pemeriksaan neurologi, kardiologi, oftalmologi, ankle brachial index, dan elektrokardiografi yang telah dilakukan pada pasien. Karakteristik subjek, komplikasi kronis, dan hubungannya dengan faktor-faktor risiko, seperti kontrol glikemik menggunakan HbA1c, glukosa darah puasa, durasi diabetes, dan kolesterol LDL dianalisis dengan uji kai kuadrat (chi square).

Hasil: Dari 155 subjek, sebagian besar perempuan (59\%) dan berusia lanjut (46\%). Prevalensi komplikasi kronis diabetes adalah 69\%. Komplikasi kronis ini terdiri dari mikroangiopati $56 \%$, makroangiopati 7\%, dan kombinasi keduanya 27\%. Mikroangiopati mencakup nefropati diabetik (2\%), retinopati diabetik (7\%), neuropatidiabetik (38\%), serta campuran (53\%). Makroangiopati mencakup penyakit jantung koroner (46\%), penyakit arteri perifer (19\%), stroke (18\%), dan campuran (17\%). Kami mendapatkan hubungan yang bermakna secara statistik antara durasi diabetes dan neuropati diabetik (nilai $p$ $=0,003$ ).

Kesimpulan: Prevalensi komplikasi kronis diabetes di Poliklinik Rawat Jalan Diabetes di Rumah Sakit Cipto Mangunkusumo didominasi oleh komplikasi mikrovaskular mencakup nefropati diabetik, retinopati diabetik, neuropati diabetik dan campuran. Terdapat hubungan yang bermakna secara statistik antara durasi diabetes dan neuropati diabetik.

\section{ABSTRACT}

Background: Chronic complications of diabetes mellitus have a significant role in increasing morbidity, mortality, disability, and health cost. In the outpatient setting, the availability of data regarding to the chronic complications of type 2 diabetes is useful for evaluation of prevention, education, and patient's treatment. This study aimed to describe the characteristic of type 2 diabetes chronic complications in outpatient diabetes clinic.

Methods: A cross-sectional study was done using 155 patients in Outpatient Diabetes Clinic of Cipto Mangunkusumo Hospital (RSCM), Jakarta in 2010. Secondary data were used from medical record based on history taking, physical examination, diabetic foot assessment, laboratory, neurologic, cardiology, opthalmology, ankle brachial index, and electrography of the patients. Characteristic profiles of the subjects, prevalence of the chronic complications, and its association with diabetes risk factors, such as glycemic control using HbA1c, fasting blood glucose, duration of diabetes, and LDL cholesterol were analyzed using chi square test.

Results: Among 155 subjects participated in the study, most of them were women (59\%) and elderly (46\%). The prevalence of diabetes chronic complications was $69 \%$ from all subjects. These chronic complications included microangiopathy, macroangiopathy and mixed complications, with prevalence of $56 \%, 7 \%$ and $27 \%$ respectively. Microangiopathy included nephropathy (2\%), retinopathy (7\%), neuropathy $(38 \%)$ and mixed complications (53\%). Macroangiopathy included coronary heart disease $(46 \%)$, peripheral arterial disease $(19 \%)$, stroke $(18 \%)$, and mixed complication $(17 \%)$. From the analysis, we found significant association between duration of diabetes and diabetic neuropathy $(p=0.003)$.

Conclusion: Prevalence of diabetes chronic complications in Outpatient Diabetes Clinic of Cipto Mangunkusumo Hospital, mainly dominated by microvascular-related complications including nephropathy, retinopathy, neuropathy and mixed complications. There was statistical significance between diabetes duration and diabetic neuropathy.

Keywords: diabetes chronic complications, diabetic neuropathy, macrovascular, microvascular, type 2 diabetes

pISSN: 0853-1773 • eISSN: 2252-8083 • http://dx.doi.org/10.13181/mji.v24i3.1249 • Med J Indones. 2015;24:156-62

- Received 03 Jun 2014 • Accepted 27 Sep 2014

Correspondence author: Tri J.E. Tarigan, tje_tar@yahoo.com

Copyright @ 2015 Authors. This is an open access article distributed under the terms of the Creative Commons Attribution-NonCommercialShareAlike 4.0 International License (http://creativecommons.org/licenses/by-nc-sa/4.0/), which permits unrestricted non-commercial use, distribution, and reproduction in any medium, provided the original author and source are properly cited. 
Type 2 diabetes chronic complications have increased morbidity and mortality around the world. ${ }^{1-3}$ Previous studies showed that diabetes patients are high risk to suffer from complications in the form of microvascular and macrovascular disorders. Multicentre studies in China and Micronesia which gathered data from outpatients, found that diabetes chronic complications prevalence rate is exceedingly high. ${ }^{2}$ At least one chronic complication was diagnosed in $52 \%$ of the study subjects which consisted of $33.4 \%$ presented with macrovascular complications and $34.7 \%$ presented with microvascular complications. ${ }^{2}$ This is related to poor glycemic control and failure to reach treatment goals, especially in outpatients setting., ${ }^{2,3}$

Patients in outpatient settings are prone to have low compliance of therapies, not adequate monitoring, and bias or unreliable laboratory results. ${ }^{2}$ Type 2 diabetes patients with chronic complications have higher risk to be hospitalized. This trend may be caused by a higher need of hospital care to manage the chronic complications, such as acute stroke, acute heart attack, severe kidney failure, and diabetic foot problems. Approximately $60 \%$ of medical costs have been spent for various problems of diabetes chronic complications. ${ }^{1}$

Classification of chronic complications is divided into macrovascular and microvascular complications. Macrovascular complications consist of coronary heartdisease (CHD), peripheral artery disease (PAD), and cerebrovascular disease (CVD) or stroke. Microvascular complications consist of diabetic nephropathy, diabetic retinopathy, diabetic neuropathy. ${ }^{2}$ The most common chronic complications are coronary heart disease and stroke which constitute about $65 \%$ of mortality. ${ }^{1,4}$ Meanwhile, complications such as retinopathy, stroke, and diabetic foot are the main causes of disability related to diabetes. ${ }^{4}$ In Indonesia, stroke remains the most frequent cause of death. ${ }^{5}$ In short, complications increase mortality, morbidity, disability, and cost. ${ }^{6,7}$

Prevalence, demographic profiles, and clinical status of type 2 diabetes mellitus patients with chronic complications in outpatient setting in Indonesia have not been much studied. This study aimed to know the prevalence and explore characteristics of type 2 diabetes patients with chronic complications in Outpatient Diabetes Clinic of Cipto Mangunkusumo Hospital.

\section{METHODS}

This study was a cross-sectional study held in Outpatient Diabetes Clinic, Department of Internal Medicine, Cipto Mangunkusumo Hospital, Jakarta which is the top referral diabetes outpatient clinic in Indonesia. We used secondary data from medical records of patients attended the clinic at 2010 with following inclusion criteria: (1) having type 2 diabetes mellitus based on Indonesian Society of Endocrinology (Perkumpulan Endokrinologi Indonesia - PERKENI) Guideline, and (2) being treated with standard therapy for type 2 diabetes mellitus based on PERKENI Guideline for the last one year by endocrinologist (consultant), internist - fellow endocrinologist, or resident training in endocrinology department. The exclusion criteria in our study were not underwent nor completed all examination for chronic complications assessment in the last one year.

From 2,358 diabetes patients who attended our clinic from January to December 2010, we found 155 patients completed all examination to assess chronic complications which consisted of history taking for demographic characteristics, comorbidities (hypertension), risk factors (duration of diabetes, smoking habit), and history of medication, physical examination including complete diabetic foot examination, laboratory (HbA1c, lipid profiles, microalbuminuria, fasting blood glucose), neurology (neurosensory and neuromotoric examination), cardiology (electrocardiography), ophtalmology (retinal screening), and ankle brachial index (ABI) for examination of coronary artery disease, nephropathy, neuropathy, peripheral artery disease, and retinopathy complications. Association analysis between chronic complications and its risk factors (glycemic control using $\mathrm{HbA1c}$, fasting blood glucose, duration of diabetes, and LDL cholesterol) were accomplished using chi square test.

Diabetic nephropathy was diagnosed when subject had microalbuminuria (urine protein upper than $30 \mathrm{mg} / \mathrm{L}$ or incipient diabetic nephropathy). Diabetic retinopathy was 
diagnosed from retinal examination (nonproliferative diabetic retinopathy or proliferative diabetic retinopathy). Neuropathy was diagnosed from history taking and foot examination, while peripheral arterial disease (PAD) was diagnosed when ankle brachial index examination was less than 0.8. LDL cholesterol was categorized less than $70 \mathrm{mg} / \mathrm{dL}$ (optimal), 70-100 mg/dL, 100-130 $\mathrm{mg} / \mathrm{dL}$, and more than $130 \mathrm{mg} / \mathrm{dL}$, while category for glycemic control used HbA1c level which was divided into upper and lower than $7 \%$ according to Indonesian Society for Endocrinology (PERKENI) Guidelines. Duration of diabetes was defined as length time since the first medical contact which give diagnosis and medication for the patients, it can be in Cipto Mangunkusumo Hospital or from primary health care or private practice.

This study used the latest examination of the subjects from the last one year. If subjects visited our clinic more than one time in the following year, we used the latest examination data for analysis. The study used secondary data from medical records, therefore, did not require ethical approval from Health Research Ethics Committee. Confidentiality of subject identity was guaranteed.

\section{RESULTS}

From 2,358 patients in 2010, 155 subjects met the inclusion criteria and completed all examination needed in the study. From 155 subjects, most were female (59\%), elderly (46\%), and unemployed (75\%). The ethnicity and education background scattered with the Javanese (27\%) and high school graduates (39\%) as majority (Table 1 ).

Some important factors which lead to complication of type 2 diabetes are duration of the diabetes, hypertension, dyslipidemia, and HbA1c level. These factors may indicate the higher risk of chronic complications. Most of the subjects who came to the clinic had experienced type 2 diabetes for more than five years and only 5\% of them had been diagnosed type 2 diabetes since less than a year ago. More than a half of the subjects had hypertension and high HbA1c level, while one-third of them had dyslipidemia with LDL cholesterol level more than $130 \mathrm{mg} / \mathrm{dL}$ (Table 2).

This study revealed that combination of oral antidiabetic agents was the chosen therapy. Use of alpha-glucosidase inhibitors as oral anti-diabetic agents was still limited while sulfonylurea and biguanide were used on more than a half of the subjects. Glibenclamide, a cheap and widely accessed sulfonylurea, was largely used as a type of sulfonylurea (Table 3).

The prevalence of chronic complications was high (69\%). This finding corresponds with the poor clinical parameters. Microangiopathy was the most frequent complication, followed by combination of macroangiopathy and microangiopathy (37\%), while macroangiopathy was the lowest (7\%). Microangiopathy leads to organ disorders of which multiple organ disorders are the most common findings ( $53 \%$ ), followed by single organ disorders

Table 1. Demographic characteristics of the subjects

\begin{tabular}{|c|c|c|}
\hline Characteristics & Frequency & $\%$ \\
\hline \multicolumn{3}{|l|}{ Sex } \\
\hline Male & 64 & 41 \\
\hline Female & 91 & 59 \\
\hline \multicolumn{3}{|l|}{ Age } \\
\hline$\leq 30$ year & 2 & 1 \\
\hline $31-40$ year & 9 & 6 \\
\hline 41-50 year & 28 & 18 \\
\hline $51-60$ year & 45 & 29 \\
\hline$>60$ year & 71 & 46 \\
\hline \multicolumn{3}{|l|}{ Ethnicity } \\
\hline Javanese & 42 & 27 \\
\hline Sundanese & 28 & 18 \\
\hline Betawinese & 28 & 18 \\
\hline Minangnese & 12 & 8 \\
\hline Bataknese & 12 & 8 \\
\hline Others & 9 & 6 \\
\hline Unknown & 24 & 15 \\
\hline \multicolumn{3}{|l|}{ Occupation } \\
\hline Government employees & 11 & 7 \\
\hline Private sector employees & 23 & 15 \\
\hline Unemployed & 116 & 75 \\
\hline Others & 5 & 3 \\
\hline \multicolumn{3}{|l|}{ Education } \\
\hline Uneducated & 12 & 8 \\
\hline Elementary school graduates & 26 & 17 \\
\hline Junior high school graduates & 17 & 11 \\
\hline Senior high school graduates & 60 & 39 \\
\hline College graduates & 22 & 14 \\
\hline Postgraduate & 2 & 1 \\
\hline Others & 16 & 10 \\
\hline
\end{tabular}


including diabetic neuropathy, diabetic retinopathy, and diabetic nephropathy. The most common complication of macroangiopathy is coronary artery disease, while the most common complications from microangiopathy are mixed disorders (53\%). Table 3-6 showed relationships between chronic complications and associated variables, such as HbA1c, LDL cholesterol, fasting blood glucose (FBG) and duration of diabetes (Table 4).

While in some studies, glycemic control, duration of type 2 diabetes, and lipid profile are related to some complications, this study did not show any statistical significant for several associations. There was no significant association between some characteristics of the patients to some complications, except the duration of type 2 diabetes to the occurrence of neuropathy (Table 5).

\section{DISCUSSION}

Characteristics of outpatient diabetes clinic are different from inpatient diabetes patients (hospitalized patients). ${ }^{8-12}$ Patients in outpatient clinics are able to care at home and control their disease by themselves. The glycemic level

Table 2. Characteristics of type 2 diabetes

\begin{tabular}{|c|c|c|}
\hline Characteristics & Frequency & $\%$ \\
\hline \multicolumn{3}{|c|}{ Duration of type 2 diabetes } \\
\hline$<1$ year & 8 & 5 \\
\hline $1-3$ years & 19 & 12 \\
\hline $3-5$ years & 16 & 10 \\
\hline$>5$ years & 112 & 73 \\
\hline \multicolumn{3}{|l|}{ Smoking habit } \\
\hline Smokers & 22 & 14 \\
\hline Non-Smokers & 122 & 79 \\
\hline Ex-Smokers & 11 & 7 \\
\hline \multicolumn{3}{|l|}{ Hypertension } \\
\hline Yes & 95 & 61 \\
\hline No & 60 & 39 \\
\hline \multicolumn{3}{|l|}{ LDL cholesterol } \\
\hline$<70 \mathrm{mg} / \mathrm{dL}$ & 23 & 15 \\
\hline $70-100 \mathrm{mg} / \mathrm{dL}$ & 33 & 21 \\
\hline $100-130 \mathrm{mg} / \mathrm{dL}$ & 48 & 31 \\
\hline$>130 \mathrm{mg} / \mathrm{dL}$ & 51 & 33 \\
\hline \multicolumn{3}{|l|}{ HbA1c level } \\
\hline$\leq 7 \%$ & 45 & 29 \\
\hline$>7 \%$ & 110 & 71 \\
\hline
\end{tabular}

indicates the quality of home care, adherence and compliance to medications, and the successful of self monitoring blood glucose (SMBG). The poor glycemic control tends to some complications, either acute or chronic complications. Compared to hospitalized cases, data from outpatient clinics revealed more accurate and reliable glycemic control of the patients. In the outpatient clinics, we can predict some complication related to type 2 diabetes through the assessment of the glycemic

Table 3. The diabetes therapy of the subjects

\begin{tabular}{lcc}
\hline Characteristics & Frequency & $\%$ \\
\hline Therapy & & \\
$\quad$ Oral antidiabetic agents & 73 & 47 \\
\hline Insulin & 47 & 30 \\
\hline Combination therapy & 35 & 23 \\
\hline Oral antidiabetic agents $(\mathrm{n}=108)$ & & \\
$\quad$ Sulfonylurea & 29 & 27 \\
\hline Alpha glucosidase inhibitors & 3 & 3 \\
\hline Biguanide & 30 & 28 \\
\hline Combination & 46 & 42 \\
\hline Sulfonylurea (n=75) & & \\
$\quad$ Glibenclamide & 38 & 50 \\
\hline Gliclazid & 5 & 6 \\
\hline Gliquidone & 28 & 38 \\
\hline Glimepiride & 1 & 2 \\
\hline Combination & 3 & 4 \\
\hline
\end{tabular}

Table 4. Chronic complications of diabetes

\begin{tabular}{lcc}
\hline Complications & Frequency & $\%$ \\
\hline Type of complication $(\mathrm{n}=155)$ & & \\
\hline Macroangiopathy & 11 & 7 \\
\hline Microangiopathy & 87 & 56 \\
Combination (both) & 57 & 37 \\
\hline
\end{tabular}

Microangiopathy-related complications ( $\mathrm{n}=144)$

$\begin{array}{lcc}\text { Retinopathy } & 10 & 7 \\ \text { Nephropathy } & 3 & 2 \\ \text { Neuropathy } & 55 & 38 \\ \text { Mixed } & 76 & 53\end{array}$

Macroangiopathy-related complications $(\mathrm{n}=68)$

\begin{tabular}{lll} 
Coronary artery disease & 31 & 46 \\
Stroke & 12 & 18 \\
Peripheral artery disease (PAD) & 13 & 19 \\
Mixed & 12 & 17 \\
\hline
\end{tabular}


Table 5. Association ( $\mathrm{p}$ value) between related factors (categorized) and several organ-related chronic complications

\begin{tabular}{lcccccc}
\hline Complications & Retinopathy & Nephropathy & Neuropathy & CAD & Stroke & PAD \\
\hline HbA1c $(\leq 7 \%$ versus $>7 \%)$ & 0.343 & 0.376 & 0.269 & 0.411 & 0.081 & 0.533 \\
LDL cholesterol $(<70,70-100,100-130,>130)$ & 0.324 & 0.348 & 0.136 & $1.000^{*}$ & 0.424 & $0.350^{*}$ \\
$\begin{array}{l}\text { Duration of diabetes }(<1 \text { year, 1-3 years, } \\
\text { 3-5 years, }>\text { 5 years) }\end{array}$ & 0.475 & 0.661 & $0.003^{*}$ & 0.869 & 0.536 & $0.708^{*}$ \\
Fasting blood glucose (normal versus high) & 0.311 & 0.434 & $0.116^{*}$ & 0.346 & 0.257 & 0.599 \\
\hline
\end{tabular}

Fisher-exact test was applied to analyze the association; ${ }^{*}$ Chi-square test; $\mathrm{CAD}=$ coronary arterial disease; PAD = peripheral arterial disease

control, indicated by HbA1c level and FBG level, as well as duration of diabetes and lipid profiles.

Chronic complications occurred in more than a half of type 2 diabetes patients. Even though there are some differences with some studies in number and type of complications, this study showed that the prevalence of chronic complication is more than half of the subjects. Cardiac and neuropathy complications are the most dominant complications as many studies showed in outpatient settings. As mentioned in some studies, elderly patients whose age above 60 years old and poor glycemic control had significant risk to develop chronic complications, either microvascular or macrovascular. The chronic complications may be affected by the city of residence, increasing age, duration of type 2 diabetes, and strongly by glycemic control. ${ }^{2,3}$ Among them, glycemic control seems to play the most important part. ${ }^{13}$

This study assessed some risk factors including HbA1c level, duration of diabetes, FBG level, and LDL cholesterol which is related to several organrelated diabetic chronic complications. HbA1c had long been used as an accurate parameter of glycemic control since it produces a relative constant results within two to three months. ${ }^{14}$ Beside a strong correlation to diabetic neuropathy, HbA1c level may indicate more accurate than FBG level in the developing of retinopathy. Based on the finding of Cheng YJ, et al strong suspicion of retinopathy occurs when the HbA1c level achieve more than $5.5 \%{ }^{15}$ The high level of HbA1c also indicates cardiovascular disorders and microalbuminuria, ${ }^{16}$ as well as nephropathy and microalbuminuria. ${ }^{17-19}$

High level of HbA1c and LDL cholesterol link to the coronary disease-related complications..$^{20,21}$ Lowering plasma LDL cholesterol level to less than $70 \mathrm{mg} / \mathrm{dL}$ and $\mathrm{HbA1c}$ to below $6.5 \%$ has been suggested to lower the risk of occurrence of coronary disease-related complications. ${ }^{20}$ In addition to the coronary disease-related complications, HbA1c level, LDL cholesterol level, and duration of type 2 diabetes also have significant impact to develop diabetic foot ulcers. Study of diabetic foot ulcers in Dr. Moewardi Hospital, Solo raised the issue of diabetic ulcers risk factors including long duration of type 2 diabetes of more than 10 years, high plasma LDL cholesterol level, low plasma HDL cholesterol level, and poor adherence to diabetes medication. ${ }^{22}$

Fasting blood glucose level also correlated with occurrence of diabetic nephropathy. From study of Cheng, et al FBG level above $104.4 \mathrm{mg} / \mathrm{dL}$ may increase the risk of diabetic nephropathy. ${ }^{15}$ Despite its weakness, FBG is a good predictor for complications, cheaper, and more practical in daily practice. Both FBG and HbA1c levels had been good diagnostic value and suggested to be used as parameters to predict diabetes and its complications. To obtain a proper cut-off point for Asian population, we require further studies on risk level of FBG and HbA1c.

Beside HbA1c and FBG levels, duration of diabetes is other risk factor for complication that has much been studied recently. The duration of diabetes is related to the formation of fibroatheroma which forms the origin of coronary heart disease spectrum, the risk of plaque rupture, and coronary attack events. ${ }^{23}$ Other risk factors which were not assessed in this study are age and homocystein level, while these two variables are correlated with peripheral arterial disease in type 2 diabetes patients. ${ }^{24}$

These findings have controlled several important variables like clinical characteristics and 
diabetes therapy. The duration is also related to the coronary disease risk and its increased mortality rate. ${ }^{25}$ The coronary artery disease risk increases by 1.38 fold, while coronary disease-related mortality risk increases by 1.86 fold within 10 years in addition to duration of disease. Duration of diabetes theoretically is related with all diabetic microvascular and macrovascular complications. ${ }^{23,25}$ Nevertheless, since there are some limitations on the number of subjects in this study, we only acquire a statistically significant result in the relation of diabetes duration and development of diabetic neuropathy $(\mathrm{p}=0.003)$.

Since there is not much study which assessed diabetes chronic complications in outpatient setting in Indonesia, and no data published from other diabetes centres, this study hopefully can provide database for prevalence of macro- and microvascular complications and its association with risk factors in type 2 diabetes patients in Indonesia. The limitation of the study is the risk for selection bias since there are only 155 patients out from 2,358 patients who are being included in the study caused by completeness of the chronic complication examinations needed in the study.

In general, this study portrays a current view of diabetic chronic complications occurrence in Cipto Mangunkusumo Hospital. The association between related factors (HbA1c level, FBG, diabetes duration, and LDL cholesterol level) with various chronic complications that statistically insignificant were probably caused by limitations in subjects number in the study. In the future, some strategies are developed in order to acquire a better statistic results, i.e., (1) involving other centres to achieve bigger target population, e.g., other big cities in Indonesia (multicentre study); (2) lengthening the observation period (patients visit more than one year observation); (3) endorsing complete examination of chronic complications for every patients who attend the outpatient clinic as the standard therapy of all diabetes patients who come to national referral hospital in Indonesia. Moreover, additional analysis of the relationship between other risk factors, such as blood pressure and age are required as well, since both are theoreticallyand clinically-linked with the risk of having complications.
This study revealed that some factors need to be improved and studied which are (1) early detection for chronic complications by using checklist methods so we can give early and aggresive intervention for patients who are at risk and who have been developed early stage of diabetes chronic complications; (2) increase the time of education and the role of diabetes educators for all diabetes mellitus patients, (3) close monitoring of standard therapy given in outpatient diabetes clinic. These strategies are hopefully can be solutions to decrease the prevalence of chronic complications of diabetes patients in outpatient setting.

In conclusion, our study found the prevalence of diabetes chronic complications in Outpatient Diabetes Clinic of Cipto Mangunkusumo Hospital was $69 \%$, mainly dominated by microvascularrelated complications (56\%) including nephropathy (2\%), retinopathy (7\%), neuropathy (38\%) and mixed complications (53\%). There is statistical significancy between diabetes duration and diabetic neuropathy. In the purpose to prevent the complications, glycemic control plays a pivotal role. The duration of type 2 diabetes and poor lipid profile may increase the risk. However, we require further studies with larger number of subjects with larger scope (multicentre study) to describe chronic complications in type 2 diabetes patients in Indonesia.

\section{Acknowledgement}

We would like to thank Division of Endocrinology and Metabolism, Department of Internal Medicine Faculty of Medicine University of Indonesia/ Cipto Mangunkusumo Hospital and also Medical Record Unit of Cipto Mangunkusumo Hospital for the help and support to conducting this study. We would like to thank Ms. Dila Efiyanti, secretary in our division who had edited and helped the preparation of the manuscript.

\section{Conflict of interest}

The authors affirm no conflict of interest in this study.

\section{REFERENCES}

1. Olveira-Fuster G, Olvera-Márquez P, Carral-Sanlaureano F, González-Romero S, Aquilar-Diosdado M, SoriquerEscofet F. Excess hospitalizations, hospital days, and inpatient costs among people with diabetes in Andalusia Spain. Diabetes Care. 2004;27(8):1904-9. 
2. Liu Z, Fu C, Wang W, Xu B. Prevalence of chronic complications of type 2 diabetes mellitus in outpatients - a cross-sectional hospital based survey in urban China. Health Qual Life Outcomes. 2010;8(62):1-9.

3. Karki P, Bhandary S, Korean M, Braind K. Diabetes and its macrovascular and microvascular manifestations among Micronesian populations. J Nepal Med Assoc. 2003;42:337-40.

4. Schoolwalk.diabetes.org [Internet]. American Diabetes Association [cited Nov 2010]. Available from: http:// schoolwalk.diabetes.org/

5. Badan Penelitian dan Pengembangan Kesehatan. Riset Kesehatan Dasar; Laporan Nasional 2007. Departemen Kesehatan Republik Indonesia, 2008; 156-60. Indonesian

6. Clarke PM, Glasziou P, Patel A, Chalmers J, Woodward M, Harrap SB, et al. Event rates, hospital utilization, and costs associated with major complications of diabetes: a multicountry comparative analysis. PLoS Med. 2010;7(2):e1000236.

7. Grover S, Avasthi A, Bhansali A, Chakrabarti S, Kulhara P. Cost of ambulatory care of diabetes mellitus: a study from north India. Postgrad Med J. 2005;81(956):391-5.

8. Donner TW. Tight control of hyperglycemia in type 2 diabetes mellitus. Insulin. 2006;1(4):166-72.

9. Moghissi ES, Korytkowski MT, DiNardo M, Einhorn D, Hellman R, Hirsch IB, et al. American Association of Clinical Endocrinologists and American Diabetes Association Consensus statement on inpatient glycemic control. Diabetes Care. 2009;32(6):1119-31.

10. Home P. Outpatient and inpatient diabetes care delivery. Diabetes Voice. 2006;51(suppl):5-8.

11. Deepak PJ, Sunitha K, Nagaraj J, Sanjukta A, Bhattacharyya A. Inpatient management of diabetes: survey in a tertiary care centre. Postgrad Med J. 2003;79:585-7.

12. Van Zyl DG, Rheeder P. Inpatient blood glucose management of diabetic patients in a large secondary hospital. S Afr Fam Pract. 2009;51(2):162-5.

13. Zatalia ST, Sanusi H. The role of antioxidants in the pathophysiology, complications, and management of diabetes mellitus. Acta Med Indones. 2013;45(2):141-7.

14. Soewondo P. New Indonesian Society for Endocrinology (PERKENI) Guidelines for Prevention and Management of Type 2 Diabetes and Its Supporting Evidence. Proceeding Book Jakarta Diabetes Meeting; Jakarta: 2010.
15. Cheng YJ, Gregg EW, Geiss LS, Imperatore G, Williams $\mathrm{DE}$, Zhang $\mathrm{X}$, et al. Association of A1C and fasting plasma glucose levels with diabetic retinopathy prevalence in the US Population: implications for diabetes diagnostic thresholds. Diabetes Care. 2009;32(11):2027-32.

16. Wadén J, Forsblom C, Thorn LM, Gordin D, Saraheimo M, Groop PH, et al. A1C variability predicts incident cardiovascular events, microalbuminuria, and overt diabetic nephropathy in patients with type 1 diabetes. Diabetes. 2009;58(11):2649-55.

17. Mataradzija A, Resić H, Rasić S, Kukavica N, Masnić F. Risk factors for development of cardiovascular complications in patients with chronic renal disease and diabetic nephropathy. Bosnian J Basic Med Sci. 2010;10(suppl):S44-50.

18. Arsono S. Diabetes sebagai faktor risiko kejadian gagal ginjal terminal [thesis]. Semarang: Universitas Diponegoro; 2005. Indonesian.

19. Unnikrishnan RI, Rema M, Pradeepa R, Deepa M, Shanthirani CS, Deepa R, et al. Prevalence and risk factors of diabetic nephropathy in an Urban South Indian Population: the Chennai Urban Rural Epidemiology Study (CURES 45). Diabetes Care 2007;30(8):2019-24.

20. Valensi P. Predicting and preventing cardiovascular risk in patients with diabetes. Eur Endocr Dis. 2007:66-7.

21. Purnamasari D. Diabetes as risk equivalent to $\mathrm{CV}$ disease: what does the guidelines tell us? Proceeding Book, Jakarta Diabetes Meeting, 2010. Indonesian.

22. Hastuti RT. Faktor-faktor risiko ulkus diabetika pada penderita diabetes melitus [thesis]. Semarang: Universitas Diponegoro; 2008. Indonesian.

23. Lindsey JB, House JA, Kennedy KF, Marso SP. Diabetes duration is associated with increased thin-cap fibroatheroma detected by intravascular ultrasound with virtual histology. Circ Cardiovasc Interv. 2009;2:543-8

24. Kuswardhani RA, Suastika K. Age and homocystein were risk factor for peripheral arterial disease in elderly with type 2 diabetes mellitus. Acta Med Indones. 2010;42(2): 94-9.

25. Fox CS, Sullivan L, D'Agostino RB Sr, Wilson PW, Framingham Heart Study. The significant effect of diabetes duration on coronary heart disease mortality: the Framingham Heart Study. Diabetes Care. 2004;27(3):704-8. 